\title{
ОСОБЕННОСТИ ДЕСТРУКЦИИ АРОМАТИЧЕСКИХ СОЕДИНЕНИЙ В ПРИБРЕЖНЫХ ВОДАХ ЗАЛИВА ЧИХАЧЕВА
}

\section{FEATURES OF THE DESTRUCTION \\ OF AROMATIC COMPOUNDS \\ IN THE COASTAL WATERS \\ OF THE CHIKHACHEVA BAY}

\section{O. Stukova}

Summary. In the work, microbiological features of the destruction of aromatic compounds in the Chikhachev Bay are considered. The method of initiated microbiocenosis is used. As the sources of pollution, there were used naphthalene, phenanthrene and phenol. In paper is shown, that due to the microbiological destruction of aromatic compounds the toxic colors products are formed.

Keywords: microbial complexes, destruction, aromatic compounds, Chikhachev bay.

\author{
Стукова Ольга Юрьевна \\ Старший преподаватель, ВО ФГБОУ «Тихоокеанский \\ государственный университет», г. Хабаровск \\ olgastukova1@rambler.ru
}

Аннотация. В работе рассмотрены особенности микробиологические деструкции ароматических соединений в заливе Чихачева. Применяли метод инициированного микробных сообществ. В качестве источников загрязнения использовали нафталин, фенантрен и фенол. В работе показано, что из-за микробиологической деструкции ароматических соединений образуются токсичные цветные продукты.

Ключевые слова: микробные комплексы, деструкция, ароматические соединения, залив Чихачева.

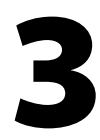
агрязнение прибрежных морских акваторий ароматическими соединениями различного происхождения является одной из актуальных экологических проблем. Ароматические соединения входят в состав нефтепродуктов, образуются в результате жизнедеятельности гидробионтов в толще воды и донных отложениях, поступают со сточными водами и поверхностным стоком. Большое количество нефтепродуктов поступает при её добыче на континентальном шельфе, а также в результате аварий речных и морских судов [1].

Нефтяные загрязнения подавляют развитие фитобентоса и фитопланктона, которые представлены сине-зелеными и диатомовыми водорослями, что снижает концентрацию кислорода в водной среде. Загрязнение водных акваторий ароматическими соединениями приводит к гибели чувствительных видов рыб, других морских животных и водоплавающих птиц, негативно влияет на их воспроизводство. При хроническом загрязнении нефтяными углеводородами и фенольными соединениями сокращаются запасы биоресурсов в морях.

Решающая роль в процессе самоочищение природных вод отводится микроорганизмам и их адаптационным возможностям. Особая биохимическая организация микробной клетки связана с ее полифункциональной ферментативной активностью. Микробные комплексы (МК) способны разрушать и обезвреживать различные токсические вещества. Микробное разрушение нефтяных загрязнений - один из важнейших процессов, способствующих самоочищению водных экосистем. В результате микробиологической деструкции ароматических соединений происходит их детоксикация, однако для этого необходимы специфические физико-химические условия. Физиологическая активность МК имеет свои пределы и определяется составом загрязнения, типом нефтяных углеводородов и их концентрацией. Степень токсичности нефти определяется количеством летучих ароматических соединений (бензол, толуол, ксилол) и нафталиновых фракций. [4]. В процессе деструкции высокомолекулярных полициклических ароматических углеводородов (ПАУ) могут накапливаться промежуточные интермедиаты, которые в отдельных случаях оказываются более токсичными, чем исходные продукты. Скорость расщепления таких субстратов будет зависеть от многих факторов, в том числе от наличия легкодоступных источников углерода, других токсичных веществ, которые в комплексе могут обладать аддитивным эффектом.

Основная задача исследований состояла в оценке способности планктонных МК из различных биотопов зал. Чихачева разрушать ароматические соединения, отличающиеся по своей структуре (фенол, нафталин, фенантрен). Объектом исследования являлись природные воды, отобранные на различных участках залива Чихачева, который расположен в северной части 


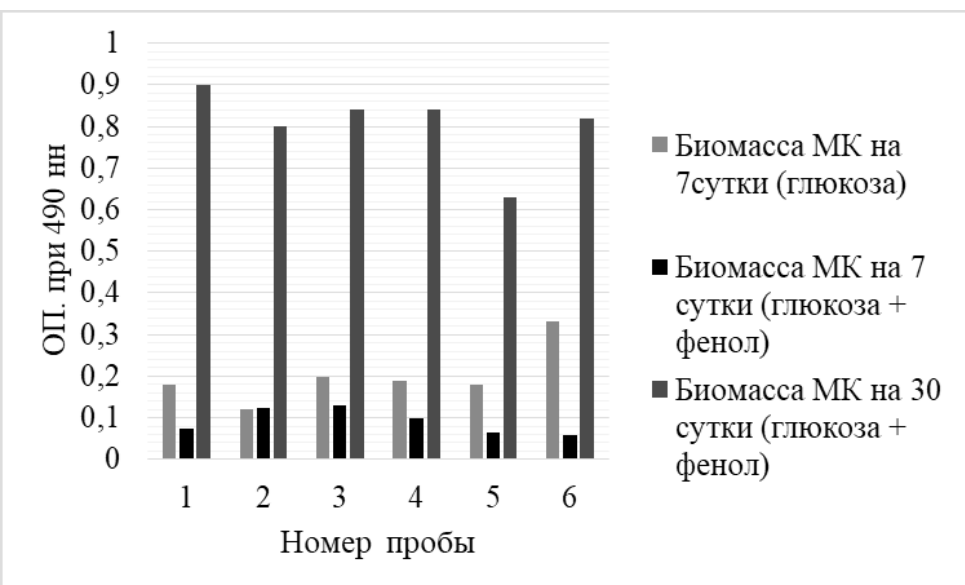

Рис. 1. Особенности роста микробных комплексов залива Чихачева (бухта Сомон) на различных источниках углерода.

Татарского пролива. Изрезанность береговой линии определило наличие нескольких бухт, которые имеют определенную специфику и свою антропогенную нагрузку. Бухта Северная примыкающая к полуострову Клыкова, на котором построен крупный нефтяной терминал в 2005 г. На берегу бухты Сомон расположен склад горюче смазочных материалов (ГСМ) и вдоль берега встречаются несанкционированные свалки. На западе в бухту впадает р. Сомон.

Первые микробиологические исследования в заливе Чихачева были проведены в 90-е годы [3]. Согласно полученным результатам качество воды прибрежных акваторий залива в значительной степени зависело от экологического состояния побережья. Основным источником антропогенной нагрузки на побережье выступал леспромхоз пос. Де-Кастри. При загрязнении прибрежной зоны древесными отходами наблюдалось активное развитие микробных комплексов, обладающих амилазной, целлюлозной и протеазной активностью. Многие бактерии, выделенные из донных отложений литорали, оказались устойчивыми к фенольным соединениям, и активно развивались на низкомолекулярных углеводородах (нонан, декан, гексадекан).

Для оценки уровня загрязнения прибрежных вод залива Чихачева ароматическими соединениями различной структуры был использован метод микробиологической индикации [2]. Для этого проводили исследования структуры МК на агаризованных селективных средах и в модельных экспериментах с различными источниками углерода (глюкоза, пептон, фенол), включая полициклические ароматические соединения (нафталин, фенантрен).

Исследования прибрежных морских вод, проведенные в 2005 г в окрестностях пос. Де-Кастри, показали, что со стоком р. Татарка выносятся продукты биодеградации полициклических ароматических углеводородов - фенольные соединения. Наиболее интенсивный рост МК на модельном бициклическом нафталине наблюдался в пробах воды отобранных в лагуне Сомон в зоне смешения. Это явление объясняется тем, что с изменением режима солености и скорости течения происходит оседание взвешенных веществ, выносимых с речным стоком с территории водосбора, среди которых могли присутствовать ПАУ и продукты их трансформации. Планктонные МК, функционирующие в бухтах Северная и Сомон, проявляли слабую активность по отношению нафталину и фенантрену.

В феврале 2008 г. исследования качества воды в заливе Чихачева впервые были проведены в период ледостава. Было отобрано 6 проб подледной воды в следующих точках бухты Сомон: 1-80-100 м напротив склада ГСМ; 2-200 м западнее склада ГСМ; 3 - южная часть бухты; 4-200 м от моста; 5 - устье р. Сомон; 6-200 м западнее мыса Мангал.

Микробиологическая индикация показала, что природные воды, отобранные западнее мыс Мангал, содержали высокие концентрации органических веществ различного происхождения. Здесь же отмечена высокая численность морских гетеротрофных бактерий, растущих на среде Youshimizи, Kimura (1976), а также фенолрезистентных микроорганизмов, которые росли на агаризованных средах при концентрации фенола 1 г/л.

В модельном эксперименте при использовании двух косубстратов было показано, что в присутствии фенола (0,5 г/л) рост на глюкозе (2 г/л) сопровождался изменением окраски культуральной жидкости. Можно предположить, что образование цветных ин- 
термедиатов обусловлено окислением фенолов до хинона (1,2-бензохинона). При этом было отмечено, что на среде, содержащей фенол и глюкозу отмечается ингибирование роста МК, возможно промежуточным продуктом трансформации. Наиболее чувствительными к интоксикации фенолом и его промежуточными цветными интермедиатами оказались МK (пробы № 5, 6), отобранные в устьевой зоне р. Сомон и в районе мыса Мангал (рис. 1). Однако фенол не вызывал ингибирования роста МК из проб воды отобранных западнее склада ГСМ (проба № 2). Есть основание предполагать, что с поверхностным стоком в прибрежные воды в летнее время поступают фенольные соединения. Они способствуют формированию МК, адаптированных к этому поллютанты.

Только спустя месяц практически все МК оказались способными в утилизации промежуточных продуктов, на которых микроорганизмы стали активно накапливать биомассу. Это факт свидетельствует о способности МК усваивать ароматические соединения в результате длительной адаптации при благоприятных абиотических условиях. В наших экспериментах температура составляла $23-25^{\circ} \mathrm{C}$. В дополнительных вариантах при температуре $5-7^{\circ} \mathrm{C}$, рост МК отсутствовал. Это значит, что в зимнее время ароматические соединения не утилизируются в водной среде из-за низкой активности МК и выступают в качестве лимитирующих факторов самоочищения природных вод.

В южной части бухты Сомон и в районе склада ГСМ была отмечена высокая активность роста планктонных МК на нафталине. Рост также сопровождался изменением цветности культуральной жидкости. Максимальная активность по отношению к фенантрену (трициклический ПАУ) была отмечена у МК, выделенных из трех различных биотопов бухты Сомон, попадающих в зону влияния склада ГСМ (пробы 1, 2, 4). Можно предположить, что МК даже в зимнее время сохраняют свою активность к трансформации ПАУ. Фактически в районе склада ГСМ происходит хроническое загрязнение прибрежных морских акваторий ароматическими соединениями различного строения. Зона влияния распространяется до южной части бухты Сомон. Планктонные МК, не испытывающие хронического загрязнения водной среды ПАУ, оказались не способными участвовать в трансформации нафталина и фенантрена. Так в устьевой зоне р. Сомон зарегистрировано минимальное накопление биомассы МК на глюкозе в присутствии фенола, они также не развивались на нафталине и фенантрене. Максимальный рост МК на легкодоступных источниках углерода зарегистрирован в водах, расположенных на западе мыса Мангал. Здесь же отмечалось ингибирование роста МК на легкодоступных источниках углерода фенольными соединениями. Это может быть связано с развитием фототрофных гидробионтов, продуцирующих автохтонное органическое вещество. Несмотря на то, что МК из этого биотопа не утилизировали фенол, они оказались резистентными к его повышенным концентрациям в водной среде до 1 г/л. Это еще раз подчеркивает, что фенолрезистентных бактерий нельзя отождествлять с фенолокисляющими МК. В этих случаях включаются различные внутриклеточные механизмы.

Таким образом, модельные эксперименты с природной водой показали, что в присутствии легкодоступных органических веществ (глюкоза) происходит медленная микробиологическая деструкция фенола, с образованием цветных продуктов. Утилизация фенола и продуктов его трансформации происходит в результате длительной адаптации МК (в течение 30 суток) при благоприятном температурном режиме $\left(23-25^{\circ} \mathrm{C}\right)$. Особой активностью отличались МК, функционирующие в бухте Сомон в зоне влияния склада ГСМ. Согласно микробиологической индикации природных вод в заливе Чихачева существует экологический риск вторичного загрязнения водных масс растворенными интермедиатами микробиологической деструкции нефтепродуктов. Они могут выступать в роли токсикантов, наряду с исходными нефтепродуктами, способными аккумулироваться в тканях гидробионтов и передаваться по трофическим цепям морских экосистем; вызывать мутагенный, тератогенный, канцерогенный, летальный и другие отрицательные эффекты.

\section{ЛИТЕРАТУРА}

1. Долотов Ю.С. Проблемы рационального использования и охраны прибрежных областей Мирового океана. М.: Научный мир, 1996. 304 с.

2. Кондратьева Л.М., Фишер Н.К., Стукова 0.Ю., Золотухина Г.Ф. Загрязнение реки Амур полиароматическими углеводородами // Вестник ДВО РАН, 2007. № 4. С. 17-26.

3. Кондратьева Л.М., Павлюшина О.В. Разнообразие микробного сообщества литорали в условиях антропогенного загрязнения // Биология моря, 1991. № 3. C. 38-45.

4. Hartmans S., Bont J., Harder W. Microbial metabolism of shot chain unsaturated hydrocarbons // FEMS Microbial. Rev., 1989. Vol. 63. № 3. P. 235-264.

(с) Стукова Ольга Юрьевна ( olgastukova1@rambler.ru).

Журнал «Современная наука: актуальные проблемы теории и практики» 